UDC 378:373.011.3-051:140.8]:37.014.3

DOI: $10.52534 / \mathrm{msu}-\mathrm{pp} .7(3) .2021 .102-109$

\author{
Nataliia V. Olkhova ${ }^{*}$ \\ Lesya Ukrainka Volyn National University \\ 43025, 13 Voli Ave., Lutsk, Ukraine
}

\title{
Development of the Ideological Culture of the Future Primary School Teacher in the Conditions of the New Ukrainian School
}

\begin{abstract}
Article's History:
Received: 20.05.2021

Revised: 15.07.2021

Accepted: 26.08 .2021

\section{Suggested Citation:}

Olkhova, N.V. (2021). Development of the ideological culture of the future primary school teacher in the conditions of the new Ukrainian school. Scientific Bulletin of Mukachevo State University. Series "Pedagogy and Psychology", 7(3), 102-109.
\end{abstract}

\begin{abstract}
The value system of the Organisation of the New Ukrainian School (NUS) aims to adapt the education system in Ukraine to progressive international standards in terms of prospects for Sustainable Development and lifelong education, while preserving the best traditions of national pedagogy. In the vector of such ambitious plans and positive prospects for qualitative transformations in education and other social existence areas, the NUS teacher's personality acquires central significance. The problem of developing a worldview culture become central. We propose to define it as a "positive worldview culture of the teacher". The study aims to mutually integrate the concepts of the worldview culture of primary school teachers and the ideological, axiological and practical aspects of the NUS implementation. In preparing the study, the authors used observation, description, complex analysis, analysis of the regulatory framework for the implementation of the NUS and the updated standard of education, functional method, comparison method, System Analysis, generalisation and abstraction. As a result, the study analysed the concept of the worldview culture of primary school teachers, defined the directions and sources of developing worldview culture of future primary school teachers, and structured the main desirable features of the worldview culture of the future teacher of NUS formed during studying at HEI. The study found out that ideological culture is associated not only with the intellectual development and assimilation of universal knowledge in a ready-made form (uncritically, without rethinking), but also with the interpretation of this knowledge in the light of personal experience, personality-oriented values and attitudes. The article substantiates the importance of organising professional training of future primary school teachers to achieve a high academic indicator of mastering knowledge, practical skills, and a generalised higher level of competence readiness, which is a professionally determined worldview culture. The study actualises the necessity to pay increased attention to the part of organising the training of future NUS teachers to the fundamentally important concept of a positive worldview culture
\end{abstract}

Keywords: worldview, worldview culture, primary school, school reform, educational reform, teacher training

\section{INTRODUCTION}

The new Ukrainian school (NUS) is conceptualised as a critical educational reform in all years of Ukraine's independence. It provides for drastic changes in the educational mechanism that meet the education system in Ukraine with advanced international standards and allow learning the best world experience. In general, modernising approaches to reforming the educational vertical go along with such relevant concepts as sustainable development and lifelong learning for the world community. At the same time, they preserve and embody the best traditions of national pedagogy. The fundamental importance of the NUS is that it is the starting point for consistent reform of the entire educational vertical. High-quality implementation of the NUS principles can catalyse qualitative educational changes and guarantee qualitative transformations of the entire social mechanism. At the same time, this process is still yielding 
results. Thus, the new Law of Ukraine, "On Education" [1], which regulates fundamental concepts and outlines the paradigm of the NUS, was adopted in September 2017. Accordingly, in February 2018, the Cabinet of Ministers of Ukraine approved a new state standard of primary education [2]. On January 16, 2020, the Law "On Full General Secondary Education" was adopted [3], which continues to develop the achievements of the NUS, updating them at a new level - in accordance with the educational needs and features of the psychophysical development of Secondary School students. Gradually, reforms in line with the values that form the axiological basis of the NUS will cover the entire education system. The system of Organisation of the transformation environment of the educational system primarily provides for the ideological transformation of participants in the educational space, where its two integrated poles (teacher, on the one hand, and student, on the other) are mutually dependent. An integral personality of the teacher, or rather those worldview attitudes that determine professional activity and manifest a common worldview culture, is a prerequisite for educating socialised, competent young people adapted to the conditions of the modern world from the lowest levels of the educational pyramid. If the teacher's worldview does not correspond to the ideological foundations underlying the NUS philosophy, the cognitive-praxeological dissonance will completely devalorise the innovative values prescribed by the charters of the reformed primary school. That is why developing a teacher's ideological culture is a matter of significant relevance and the key to a successful and consistently implemented axiological component of the NUS [4, p. 15].

Developing the ideological culture of future teachers in the process of their professional development and acquisition of professional competencies deserve special attention as well [5, p. 31]. This question has become relevant not only in Ukrainian but also in foreign scientific writings. Thus, B. Parydinova and K. Kaldybay [6, pp. 211-218] note the need to pay attention to the development of the spiritual outlook of teachers. Yet, there were some accents or specifications. That the qualities that characterise the spiritual worldview of teachers change depending on the social structure of the state and the prevailing ideology, religious and secular views, as well as the level of development of pedagogical science. The spiritual worldview of teachers is one of the essential characteristics of the pedagogical training of the individual. The development of a spiritual worldview is mutually related to the individual's moral ideal and humanistic attitudes. Seeing the issue from such a perspective is an integral part of the overall problem of developing the ideological culture of the future teacher. If to consider worldview culture as a configuration of the behaviour learned by a person and the ontological results of this configuration, the spiritual component is the driving element of the development of worldview culture. A. Senchenko and A. Borodai [7, p. 239-241] share the same opinion. Thus, the thesis about the manifestation of the ideological culture of the individual is of fundamental importance for the study not only in the function of promoting the realisation of individual spirituality, but also in the very ability of a person to spiritually transform reality. At the same time, a developed ideological culture also initiates the process of progressive, systematic spiritual improvement of the individual, expanding the boundaries of spiritual power. Ideological culture, in general, is also closely connected with the processes of self-knowledge and self-improvement, which are inherently spiritually deterministic. In the paradigm of the teaching profession, it is a catalyst for professional improvement with a life perspective (in terms of lifelong learning). The idea of future teachers about the ideological culture, its essence and functions in the structure of personal development is the basis for the personal and professional development of applicants for the profession of primary school teachers. Yet, in the future, it can be decisive for the development of the ideological culture of students. This is especially topical in line with the concept of "worldview education", which is actively developed in the studies of foreign researchers [8, p. 242-254; 9, p. 1-16].

According to the author, teachers' professional success and the educational achievements of their pupils do not depend solely on the qualities of shaping the outlook of future primary school teachers. Since young teachers with professional consciousness and already formed orientation in the direction of the NUS can assimilate better and broadcast the innovative program of primary schools and qualitatively and comprehensively influence the professional activities of their senior colleagues, the latter ones have to retrain to carry out professional activities within the NUS, which is a complex and ambiguous process. Consequently, young primary school teachers who are professionally formed in the axiological plane of the NUS can become effective facilitators in adapting to the new requirements of the professional activity of older teachers.

Now there is a clear need for a qualitative methodological generalisation: regarding the mutual integration of the concepts of the worldview culture of primary school teachers and the ideological-axiological and practical aspects of the implementation of the NUS, which constitute research objectives. This goal provides for the implementation of the spectrum research tasks: (1) to analyse the concept of the worldview culture of primary school teachers; (2) to determine the directions and sources of developing the worldview culture of future primary school teachers; (3) to structure the main desired features of the worldview culture of the future NUS teacher formed during studying at HEI; (4) to outline the prospects for further research on the topic.

\section{LITERATURE REVIEW}

The updated standard of Primary Education provides for changes concerning the educational process of younger schoolchildren and documents the need for teachers to apply innovative approaches to the organisation of pedagogical activities [2]. This stimulated large-scale retraining of primary school teachers during 2018-2019. The purpose 
of such events was to help teachers: a) in mastering the necessary knowledge and skills to work effectively in the NUS paradigm; b) in acquiring relevant competencies; c) in overcoming the stereotypical vision of the primary education system laid down by professional, ideological values that today do not meet the needs of the time and direct the task of Modern School as an important social institution that drives the entire process of qualitative social transformation [2]. The learning was conducted as distance (online) learning, localised on the EdEra platform. However, there are also more practical face-to-face sessions accompanied by specially trained coaches. Consequently, the algorithm for reforming primary schools in the direction of the NUS appropriately predicted that the first step in this direction is to adapt teachers to the new education system. However, three years of experience in implementing the NUS has shown that the ideological stereotyping of NUS teachers is one of the significant obstacles to the full implementation of the reformed educational model [2]. The ideological culture is the fundamental element of the teacher's professional personality, which, on the one hand, is essential for new standards, and on the other, is much more challenging to adapt. However, despite the importance and relevance of forming ideological foundations for the further professional success of future NUS teachers, official regulatory documents say very little about their worldview. There are isolated references to the worldview in the context of pedagogical influence on the student of the NUS, which do not concern the teacher's personality itself. In modern scientific literature, the situation with the development of the ideological culture of the future NUS teacher is not much better. Thus, there are only incidental mentions concerning philosophical origins of the development of the intellectual culture of the future NUS primary school teacher in the studies of O.A. Golyuk, N.A. Pakhalchuk [10]; A.S. Drokina [11], L.O. Dubrovska, V.L. Dubrovsky [12]; N.O. Kushnir and V.V. Shakotko [13], Z.S. Galko [14], K.S. Ovsienko [15], etc. However, the issue of the ideological culture of NUS teachers is not conceptual here. The discourse on changes and content of primary school teacher training primarily focuses on pragmatic issues of adaptation to the NUS system of the list of academic disciplines in educational and professional programs of applicants for "013 Primary education" speciality and updating the structural part of pedagogical practices [5]. There are also general issues of advanced training of pedagogy and psychology teachers. The authors pay special attention to the methods of teaching primary school subjects on cooperation pedagogy, the use of innovative pedagogical technologies, the requirements of new educational standards for learning outcomes, and primary school teachers' role in the modern educational process. Some authors also consider ensuring the right of primary school teachers to observe the autonomy of pedagogical activity [5].

Though without a particular scientific focus on the NUS system, I.A. Kovalchuk [16], Y.A. Khairullina [17], Z.M. Khitra [18] discuss the ideological foundations of the professional activity of primary school teachers in their studies. Thus, the analysis of the literature suggests that even though these authors consider the issues of developing worldview culture of the future primary school teacher, adapting the entire system of schooling, and professional training of primary school teachers to the conditions of the NUS in parallel (meaning the adaptation of the teaching system in the HEI to prepare applicants for the updated environment of education and professional activity), very little attention is paid specifically to the features of developing worldview culture of NUS primary school teachers [16-18]. The closest to the author's understanding of the basics of developing the ideological culture of future NUS teachers is the studies of O.F. Galko "The Teacher's Role in the Modern Ukrainian School" [14, p. 172], arguing that the role of the NUS teacher was not to carry information, but rather to provide individual teaching support for the students. This mission is much more challenging. The author also agrees with L.C. Ovsyenko's opinion on the system of values, forming the core of the teacher's personality and constituting the world-view basis of all spheres and aspects of teacher's activity, including professional one. It applies to the value and normative sphere of the teacher's personality [15, p. 124]. In general, the study highlights the vital significance of the philosophical markers of the teacher's personality and interconnection of work in the educational sphere (i.e., pedagogical activity) with the individual's life stance [15, p. 32]. These issues are relevant, and they appear in the paradigm of the problematic tasks of the philosophy of education.

\section{MATERIALS AND METHODS}

In the course of the study, the author applied the following methods:

- method of monitoring (the process of implementing the NUS reform, corresponding changes and adaptations of the educational process in the structure of pedagogical higher education institutions that train future primary school specialists, etc.);

- description (reflection of changes taking place in the field of primary education and training of future primary school teachers; preparation of a literature review on the research topic);

- system analysis (based on a systematic approach - to study the concept of worldview culture in a set of factors influencing its development in the structure of training applicants for pedagogical specialities);

- functional method (to characterise the functional aspects of the concept of worldview culture and to analyse the structural elements of worldview culture and factors influencing its development);

- comparison (in particular, in the process of preparing a literature review on the topic, analysing the current regulatory framework for NUS and comparing it with previous primary school standards);

- generalisation and abstraction (when drawing conclusions from the study).

The study also includes the method of analysing 
the regulatory framework for the implementation of NUS Within this framework, the authors analysed such official policy documents for the NUS implementation process as:

- Law of Ukraine "On Education" [1];

- Resolution of the Cabinet of Ministers of Ukraine "On Approval of the State Standard of Primary Education” [2];

- Law of Ukraine "On Secondary Education" [3];

- document initiated by the Ministry of Education and Science of Ukraine "The New Ukrainian School. Conceptual Principles of Secondary School Reform” [4].

The current research has an integrative character and lies at the intersection of the disciplines of "Philosophy" (worldview is one of the most fundamental concepts of philosophical knowledge) and "Pedagogy" (in particular, the problems in higher education and primary school). It corresponds to modern interdisciplinary accents and is a current requirement to solve urgent problems of pedagogy in higher education. This is especially relevant when introducing the worldview principles of NUS with a focus on the personality of the primary school teacher as the leading promoter and the driver of qualitative reformist changes in the educational vertical. On the other hand, in a broad sense, NUS aims to help the future and present generations of primary-school-age children (in the future - all who are involved in the educational process in Ukraine) in adopting fundamental attitudinal changes, which characterise ontological realities of the $21^{\text {st }}$ century. In this process, it is the teacher who has to become a facilitator. In this case, L.S. Tarasyuk's opinion on the importance of awareness of the crisis of the modern educational system [19, p. 32] is crucial for the study. According to the author, the solution depends not only on the education policy reform documents, but also on the teacher's personality. It is especially relevant for primary school teachers due to the sensitivity of the students of this age to the teacher's role as a vital translator of ideas and values about the world, and their dominants. In the light of this, it is essential to update the human and personal attitude values and rationalise the already existing ones, since they determine the content of the NUS teacher's profession. Achieving the far-sighted goal of increasing attention to the personality of the NUS teacher implies developing a new type of student personality, the core of which is the ability to think in categories of global scales. Thus, interest in the philosophical side of educational activity is primarily due to the objective and perceived role of education in solving problems on a global scale.

\section{RESULTS AND DISCUSSION}

\section{The conceptual content of NUS teacher's ideological culture}

The conceptual definition of ideological culture is not yet a thoroughly researched issue. It is part of individual culture. The philosophical culture of the individual is an element of spirituality. Through decades of discussions, researchers of the concept of ideological culture agree that ideological culture is the highest achievement of the individual. It is the spiritual and practical foundation of behaviour and an individual's integral and universal quality [16, p. 42]. An individual's worldview culture is the intellectual foundation of the relationships, dependencies and connections that a person creates in the process of developing, transmitting, and applying philosophical beliefs [20, p. 24]. According to the author, this definition is the most accurate one, and it, therefore, constitutes the basis of the study. According to this, worldview culture is an integral phenomenon, a combination of human existence and individual projection culture and worldview. Individual projection necessarily attracts a proactive component of a person. Consequently, it manifests itself via a professional paradigm of values and practices. Most modern researchers $[16 ; 18 ; 19]$ interpret the concept of worldview culture as the result of the individual's acquisition of social experience, certain ways of thinking, behaviour, and the development of activity modes (especially professional ones) so that a person can participate in the general multicultural society, transforming it into an individual deterministic variant. The process involves developing the individual's own beliefs, internal qualities and prospects for practical realisation in the context of professional activity. Culture defines the organisation of a person's professional (pedagogical) life and daily behaviour. It becomes the norm of life and determines a person's actions and inner world [16, p. 25-26]. The concept of morphology defines the construction of an individual's worldview culture. For its part, the morphology of worldview culture has three main elements-levels (Fig. 1).

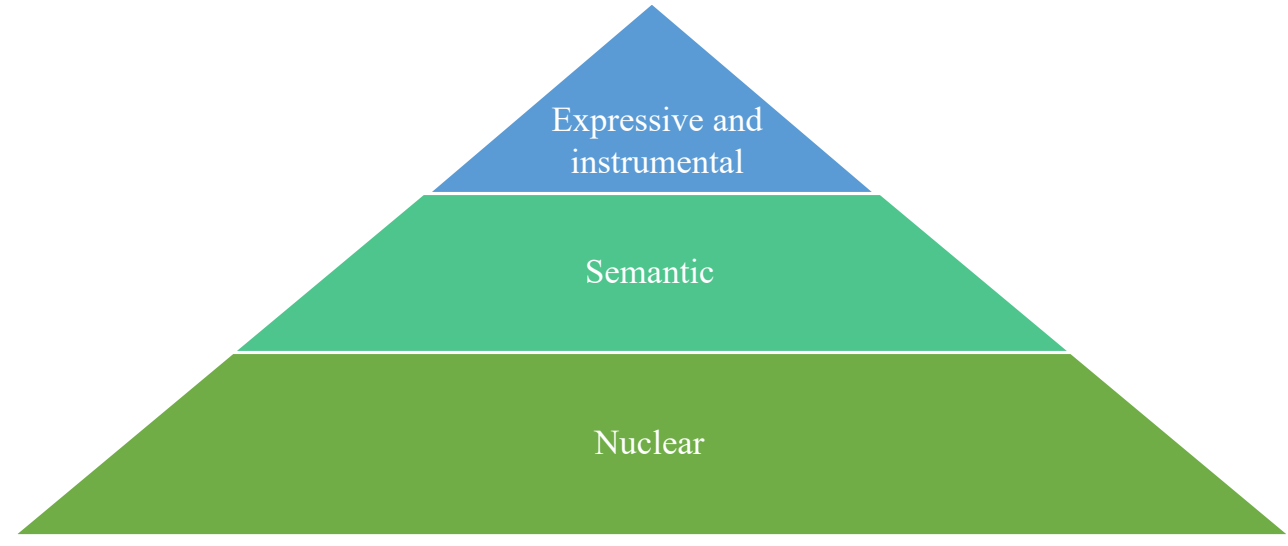

Figure 1. Morphology of worldview culture

Source: developed based on [17, p. 77-79] 
The nuclear and semantic levels cover the psychophysiological features of personality development (from neural clusters and functional constructions - knowledge and value orientations; the worldview substrate develops at this level). In terms of morphology, the expressive and instrumental level is the most important. Here the functions of worldview accumulate. They constitute the functional content of cultural origin - understanding of the world (an individual's knowledge of the surrounding world, self-awareness, acceptance, and integration into this world).

The authors will outline the concept of the worldview culture of the future NUS teacher in a professional aspect under the goals and objectives of the current study. The following markers define the degree of maturity of an individual's worldview culture, adapted to the pedagogical paradigm: a) the integrity of the teacher's personality (in particular its value and action component) b) universality, broadness of spectrum and plasticity (it is an individual's ability to deviate from programmed, instinctive forms of behaviour that determine the level of worldview culture) of pedagogical skills [17, p. 79].

The content analysis of worldview culture concepts of primary school teachers allows determining the main areas of its development, namely:

- critical and conscious attitude towards professional "Self";

- defining the paradigm of learning throughout life (given the learning process continuity and self-improvement in personal and professional aspects);

- pedagogical creativity: orientation not purely on reproductive pedagogical practices, but a clear awareness by primary school teachers of the value of their theoretical and practical search for effective models of the pedagogical activity, understanding of their self-sufficiency, the importance of themselves as a link in a single process of qualitative social transformations, where everyone creates a context for spiritual and aesthetic self-enrichment and self-growth and the corresponding enrichment of others; in particular, through the generalisation of their own teaching experience in the NUS paradigm and the publication of the results of their pedagogical search to create a high-quality constructive discussion in the pedagogical world and Ukrainian community;

- social activity - a conscious patriotic position and building a social network of relations based on the principles of democracy and tolerance.

Certain directions are determined by the Conceptual principles of secondary school reform [4] and the requirements related to the desired image of a modern school graduate, namely: 1) fully developed and multifaceted personalities, who can and used to think critically; 2) patriotically educated individuals, making responsible civil, socially significant decisions, and respecting the dignity and rights of people regardless of social and psychophysical qualities; (3) innovative students, who can qualitatively change, transform the world around them, develop the economy according to the principles of sustainable development, competitiveness in the labour market and enjoying lifelong learning $[14$, p. 6]. The correspondence of the teacher's own and the desired personal qualities and values that the teacher transmits to primary school students will create the prerequisites for the development of pedagogy of partnership, which can enrich each other in the pedagogical process [16, p. 2].

\section{The process and factors of developing the NUS teacher's worldview culture}

The concept of teacher-creator occupies a prominent place among all above-mentioned, particularly in the theoretical and practical aspects. Worldview culture develops not only through intellectual growth and assimilation of universal knowledge, but also through their interpretation in light of their personal experience and personality-oriented values and attitudes. Creative rethinking and the abandonment of standards where this can become a source of enrichment of the educational process and the personal development of a primary school student are the key elements in advancing Ukrainian pedagogy. The teachers with a high level of worldview culture must most obviously convey the same values of manifestation of their own "Selves" in pedagogy. Therefore, the creative worldview culture of the NUS teacher will also stimulate the creativity and non-standard thinking of the students.

It is worth noting that the ideological culture develops via worldview consciousness of the future NUS teacher's personality. Worldview consciousness manifests itself in the ability of a person to make independent decisions and be responsible for them, the ability to think theoretically and see the near and distant prospects of the pedagogical activity, mastering scientific principles, methods of logical analysis and interpretation of information, the ability and natural desire for independent search for truth. Practical manifestations of worldview consciousness are the skills of resolving contradictions in the individual inner world, ideological choice, and purposeful activity to implement worldview ideas and principles in practice, particularly in a professional direction. All the listed components of worldview culture and its substructures are transitional and are formed as stable and fixed (they manifest themselves as features of professional and personal orientation) at the HEI studying stage. Consequently, in the organisation of work aimed at developing the worldview culture of the applicant of the speciality "Primary Education", it is essential to consistently focus on the axiological and operational paradigm of NUS, which regulates the identity of primary-level teachers. They must be competent in developing desired life worldview culture of schoolchildren, starting from the earliest stages of their socialisation, which inevitably occurs through the institution of the school and the teacher as the promoter of the acquisition of the necessary competencies by the student. At the same time, a teacher relays values regulated by the highest State and international institutions as essential to the modern globalised and closely integrated social paradigm. 
Professional training of a future primary school teacher in the environment HEI can become the basis for developing desired models of worldview culture (we suggest using the definition of "positive worldview culture of a teacher" to determine the semantics of the desired model of worldview culture) through the appropriate organisation of the educational process. In particular, it refers primarily to its substantive and procedural aspects. After all, there is a certain dissonance, on the one hand, linked to the impossibility of simultaneously transforming the entire educational system from the top, and, on the other, to the inevitability of the need for such a transformation. This is due to the fact that it is impossible to train a future NUS primary school teacher according to stereotypical, retrograde models of higher education. Thus, it becomes clear how fundamental the changes catalysed by the NUS launch are. According to the pedagogical HEI, the goal of education in value vectors of NUS itself creates the request and forces to search for effective ways of immediate reform of approaches to prepare candidates for 013 "Primary Education" speciality. Difficulties in forming the worldview culture of a future primary school teacher are associated with the diversity of factors and sources of information that determine the applicant's worldview. However, in line with this, the HEI must assume life stance management, balancing and filtering all possible influences. General socio-cultural changes and the spontaneous influence of the media sphere on the personality of the future teacher complicate the process of building desired models of the world worldview culture [18, p. 4-5]. They can shift constructive attitudes towards devaluation of values (for example, under the influence of sexual permissiveness and eroticism, patterns of which are already being internalised by junior schoolchildren, not only by students at HEI, advertisements of uncontrolled consumption, etc).

To fully understand the concept of the worldview culture of a NUS teacher and implement the best humanistic ideas in the structure of training future primary school teachers, it is important to understand the resource base for training primary school teachers with a well-formed cultural worldview. Thus, the sources of developing the worldview of future primary school teachers are: well-prepared and NUS-oriented educational and professional programmes, thoughtful organisation of the individual, and independent work of the student; emphasis on creative, research work; personal examples of HEI teachers, their willingness to adapt to new educational requirements and their transmission of confidence in the potential of education to provoke qualitative social change; attempts to organise or train students to manage all information flows in a constructive manner (NUS strategies, for example, explicitly state that there is a shortage of modern teachers' skills in handling large amounts of information, and therefore a need to overcome this) [4, p. 2] by carefully filtering them. Other effective sources are the development of a positive worldview culture, the creation of a stable attitude to improvement and constant expansion of personal and professional qualities, which will allow the teacher to feel more comfortable in the NUS environment, and achieve better results of educational activities for young schoolchildren. Critical thinking, comparability and responsibility for action and accountable decision-making in an open non-linear system (social, political, educational, cultural, etc.) should be a central education component for future primary school teachers [21, p. 257]. The deep awareness that the basis for the training of teachers for professional activities in the New Ukrainian School is the heritage of national pedagogy contributes to the effective development of a positive outlook culture of the future teacher.

\section{CONCLUSIONS}

Thus, this study generalises and offers new valuable insights for understanding the problems of developing the worldview culture of the future primary school teacher in the conditions of the New Ukrainian School. The relevant concepts were analysed based on careful work with primary sources and the latest scientific papers, which allowed obtaining significant research results and make a contribution to filling in the gaps that currently exist in general in the development of the teacher's ideological culture. In particular, the current study contains a concept analysis of the worldview culture of primary school teachers. It defines the directions and sources of developing the worldview culture of future primary school teachers and structures the main desired features of the worldview culture of the future NUS teacher, formed within the framework of the training qualification of "Primary school teacher" at HEI.

In the study, the authors substantiate that the image of the motivated (this is how NUS defines this concept), creative and responsible teachers should be preferable in the organisation of work on developing worldview culture of the future primary teacher at the higher education institution. They are constantly working on their personal and professional development in an atmosphere of partnership between all the participants of the pedagogical process and rely on the foundations of academic freedom and unbiased attitude. In this case, teachers can manifest their worldview culture via curriculum content, textbooks, methods and strategies, innovative teaching tools and technologies, etc. The State, for its part, must guarantee freedom from undue interference in the professional activities of teachers by regulating the issue of accountability and control. Promoting innovation and diversity in the organisation of NUS teachers' professional activities will help meet the NUS conceptual principles of educating an innovative personality.

The organisation of empirical studies of diagnostics and corrective-modelling influences on the developing worldview of a future primary school teacher in the NUS environment and finding effective ways to overcome professional dissonance about desired and actual levels of NUS teachers' attitudes of different age groups are promising areas for further research on the topic. Due to the deep educational reform, they would accelerate the results of qualitative changes. 


\section{REFERENCES}

[1] Law of Ukraine No. 2145-VIII “On Education". (2017, September). Retrieved from https://zakon.rada.gov.ua/laws/ show/2145-19/ed20170905\#Text.

[2] Law of Ukraine No. 463-IX "About Complete General Secondary Education". (2020, January). Retrieved from https://zakon.rada.gov.ua/laws/show/463-20/ed20200116\#Text.

[3] Resolution of the Cabinet of Ministers of Ukraine No. 87 "On Approval of the State Standard of Primary Education". (2018, February). Retrieved from https://www.kmu.gov.ua/npas/pro-zatverdzhennya-derzhavnogo-standartupochatkovoyi-osviti.

[4] The New Ukrainian school. Conceptual principles of secondary school reform. (2017). Retrieved from https://mon.gov. ua/storage/app/media/zagalna\%20serednya/Book-ENG.pdf.

[5] Bibik, N.M. (Ed.). (2017). New Ukrainian school. Kyiv: TOV "Vydavnychyi dim "Pleiady".

[6] Paridinova, B., \& Kaldybay, K. (2020). Importance of spiritual worldview for future teachers. Bulletin of National Academy of Sciences of the Republic of Kazakhstan, 3(385), 211-218.

[7] Senchenko, A., \& Borodai, A. (2013). The meaning and purpose of ideological culture in social and cultural existence of man: The existential dimension. Gileya: Scientific Bulletin, 73, 239-241.

[8] Gardner, R.S., Soules, K., \& Valk, J. (2017). The urgent need for teacher preparation in religious and secular worldview education. Religious Education, 112(3), 242-254.

[9] Lemettinen, J., Hirvonen, E., \& Ubani, M. (2021). Is worldview education achieved in schools? A study of Finnish teachers' perceptions of worldview education as a component of basic education. Journal of Beliefs \& Values, 1, 1-16.

[10] Holiuk, O.A., \& Pakhalchuk, N.O. (2019). Features of pedagogical interaction between teacher and students in modern primary school. In L.V. Zadorozhna-Kniahnytska (Ed.), The new Ukrainian school in the conditions of modern challenges: materials of the scientific and practical conference (pp. 14-17). Mariupol: MNU.

[11] Drokina, A.S. (2020). Formation of information competence of future primary school teachers in the process of professional training (Candidate dissertation, Ukrainian Engineering Pedagogics Academy, Kharkiv, Ukraine).

[12] Dubrovska, L.O., \& Dubrovskyi, V.L. (2019). To the issue of future primary school teacher's preparation in higher education establislunents. Young Scientist, 5.2(69.2), 52-55.

[13] Kushnir, N.O., \& Shakotko, V.V. (2019). Training teachers of primary education and challenges of New Ukrainian school. Bulletin of Oleksandr Dovzhenko Hlukhiv National Pedagogical University. Pedagogical Sciences, 39, 92-99.

[14] Halko, O.F. (2020). The role of a teacher of the modern Ukrainian school. In Philosophical and worldview and cultural contexts continuing education: Materials of the scientific and practical conference with international participation (pp. 171-173). Dnipro: SPD “Okhotnik" V.S.

[15] Ovsiienko, K.S. (2020). Philosophical reflection of the phenomenon of education management. In Philosophical and worldview and cultural contexts continuing education: Materials of the scientific and practical conference with international participation (pp. 28-30). Dnipro: SPD "Okhotnik" V.S.

[16] Kovalchuk, I.A. (2014). Ideological culture of future primary school teachers: Criteria analysis. Updating the Content, Forms and Methods of Teaching and Education in Educational Institutions, 10(53), 124-127.

[17] Khairullina, Yu.O. (2014). Indicators of the degree of formation of the worldview culture of the individual. Politilogy Bulletin, 72, 77-84.

[18] Khytra, Z.M. (2010). The problem of formation of worldviews of a modern primary school teacher. In Professional adaptation of a young teacher in the conditions of changes in the value paradigm of society: Materials of the scientific and practical conference (pp. 93-96). Kyiv: Borys Grinchenko Kyiv University.

[19] Tarasiuk, L.S. (2020). Philosophical reflection of the phenomenon of education management. In Philosophical and worldview and cultural contexts continuing education: Materials of the scientific and practical conference with international participation (pp. 31-34). Dnipro: SPD "Okhotnik" V.S.

[20] Balsis, A.B. (1981). Alignment of human life and society: Features of the becoming, formation and development of the scientific materialist world outlook of workers in a mature socialist society. Vilnius: Mintis.

[21] Dovbnya, V.M. (2018). New Ukrainian school: An attempt of philosophical and anthropological comprehension. Philosophy of Education, 22(1), 240-258. 


\section{Наталія Володимирівна Ольхова}

Волинський національний університет імені Лесі Українки

43025, просп. Волі, 13, м. Луцьк, Україна

\section{Формування світоглядної культури майбутнього вчителя початкових класів в умовах Нової української школи}

Анотація. Ціннісна система організації Нової української школи (НУШ) покликана адаптувати систему освіти в Україні до прогресивних світових стандартів у річищі перспектив сталого розвитку та освіти впродовж життя з одночасним збереженням найкращих традицій національної педагогіки. У векторі таких амбітних планів і позитивних перспектив якісних перетворень в освіті та інших галузях соціального буття особистість педагога НУШ набуває центрального значення й концептуалізується довкола проблеми формування світоглядної культури, яку пропонуємо конкретизувати означенням «позитивної світоглядної культури педагога». Метою дослідження $є$ взаємна інтеграція концептів світоглядної культури вчителя початкових класів та ідейно-аксіологічної й практичної сторін імплементації НУШ. У процесі підготовки дослідження було використано методи спостереження, опису, комплексного аналізу, аналізу нормативно-регулятивної бази щодо імплементації НУШ та оновленого стандарту освіти, функціональний метод, метод порівняння, системного аналізу, узагальнення та абстракції. У результаті проаналізовано поняття світоглядної культури вчителя початкових класів, визначено напрями та джерела формування світоглядної культури майбутніх учителів початкової школи, структуровано основні бажані риси світоглядної культури майбутнього вчителя НУШ, що формуються під час навчання в 3ВО. 3'ясовано, що світоглядна культура пов’язана не лише з інтелектуальним освоєнням та засвоєнням загальнолюдських знань у готовому вигляді (некритично, без переосмислення), а й інтерпретацією цих знань у світлі свого особистого досвіду та особистісно орієнтованих цінностей і установок. Обгрунтовано важливість організації професійної підготовки майбутніх учителів початкових класів у такий спосіб, щоб не лише досягати високого академічного показника засвоєння знань і практичних навичок, але й узагальненого вищого рівня компетентнісної готовності, яким є фахово детермінована світоглядна культура. Проведена робота актуалізує висновок про необхідність посиленої уваги з боку системи організації підготовки майбутніх учителів НУШ до принципово важливого поняття позитивної світоглядної культури

Ключові слова: світогляд, культура світогляду, початкова школа, реформа шкільництва, освітня реформа, професійна підготовка вчителів 